\title{
Using Joint Audits to Support the Auditor's Independence "A Field Study"
}

\author{
Mohamed Aly Wahdan' \\ Mahmoud Abd-Elwahab ${ }^{r}$ \\ Hanan Hosny El Balshy ${ }^{r}$
}

\section{Abstract}

The purpose of this study is to examine the impact of applying joint audits on the auditor independence through a different

' Prof. Dr. Mohamed Aly Wahdan Professor of Auditing and Vice-Dean for Postgraduate Studies and Researches, Faculty of Commerce, Menoufia University, my research interests are Auditing, AIS, IT and tax Accounting.

Email:Wahdan@msm.nl

Prof. Dr. Mahmoud Abd-Elwahab Emeritus Professor of Accounting Faculty of Commerce, Menoufia University. Research interests are financial Accounting, AIS and Auditing.

${ }^{\top}$ Hanan Hosny El Balshy Demonstrator of Accounting Department, Holds

a Master Degree in Commercial Science, Faculty of Commerce, Menoufia University, my research interests are Auditing.

Email:ananelbalshy3@yahoo.com 
group of auditors who participate in the joint audit process. In order to achieve the desired goal of the study, a field study was carried out through using the questionnaire lists and interviews with a number of auditors in different audit firms and academics.

The study found that (1) there are no significant differences among the study samples around the effect of joint audit on the auditor independence, (2) there is a significant impact of joint audit on increasing the efficiency of the auditor, (3) there is a significant relationship between the joint audit and the auditor independence, (4) there is a significant impact of joint audit application on the auditor independence. In the light of the previous conclusions, the researchers could present a group of recommendations and future studies in this direction.

تهدف الدراسة الي اختبار اثر تطبيق المر اجعة المشتركة علي استقلال المر اجع من

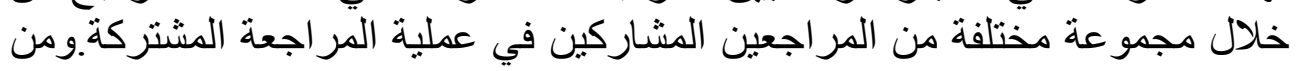

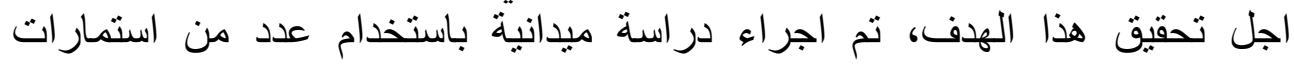

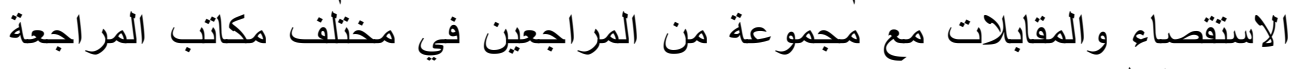
بالاضافة الي الاكاديمبين.

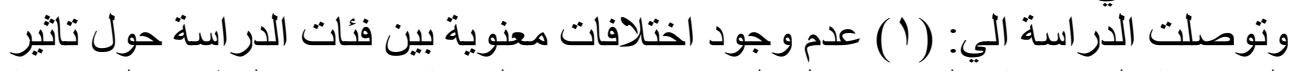

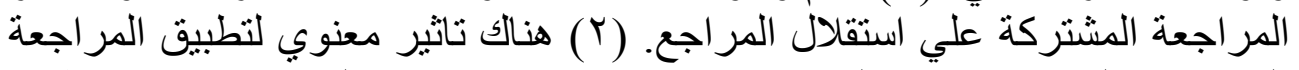

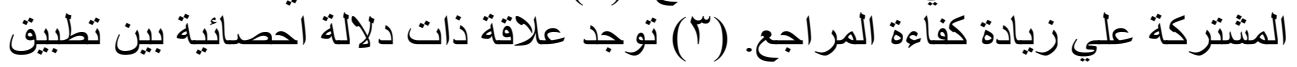

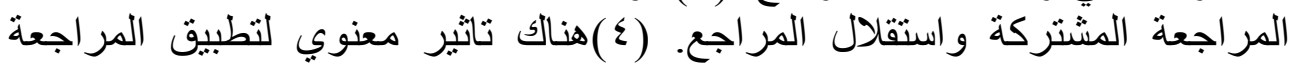

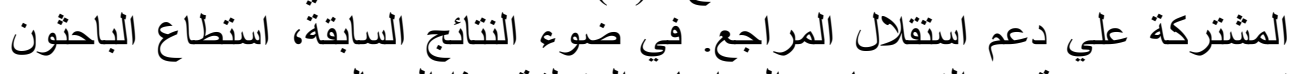

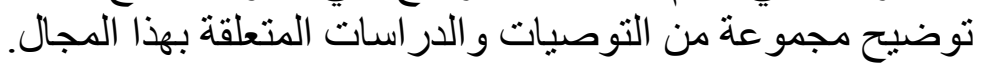

\section{Introduction}


As a result of the global financial crisis which faced the business world, a lot of questions brightened in minds about the quality of external audits, market concentration, and auditor eg. Ratzinger et al., 2013). So, there has been (independence increased concern regarding more regulations and governance to improve auditor independence which in turn leads to increase confidence in the accuracy and integrity of the financial statements. One of the most important attempts to improve the quality of audit through ensuring the independence of auditor was the mechanism of applying joint audit programs which received a great attention at all levels, as many studies have concerned with this approach and defended it because of playing an active role in improving the quality of audit. Ratzinger et al. (2012) conceptualized joint audit as a mechanism to deal with the perceived deficiencies in the function of audit which were appeared after the financial crisis (Marnet et al., 2019), It was required two independent audit firms cooperate one another in order to encourage their auditor working hardly together, enhance auditor independence, unify cooperation in addition to professional harmony, and issue just one audit report that handles

the right position of the client.

On the other hand, the independence of auditor has become an essential debatable issue especially after many economic crises. The auditor has to comply with a group of auditing standards, which differ from one country to another. Independence of external auditors may be enhanced in case of applying joint audit programs, as auditor independence is considered to be the main cornerstone in the auditing profession and practices.

The auditor independence may be negatively affected in case of the auditor gains a personal relationship with the client as this may affect their ability to conduct an unbiased opinion, as the independence lack may sometimes cause injustice problem between the audit firm and the client; in some cases it may cause 11 
bankruptcy of business and damage it as Enron and WorldCom scandals which were considered the largest bankruptcy reorganizations in American history (Al Khoury, et al., 2015). One of the threats that could lead to the lack of auditor opinion is having the same auditor for a long period of time that may mean keeping a relationship with the auditor (Al Khoury, et al., 2015). Joint audit programs can deal with most problems of the auditor independence lack.

The authors think that joint audit programs may play a role in reduction of re-drafting of the financial statements, achieving the accurate of the auditor's report, and the process of auditing can be done much faster in comparison with traditional audit in corporations that assigned its work to only one audit firm. The cooperation among audit firms stimulates the auditor on doing his best and encourages him to express his opinion impartially and objectively. These programs have an impact on improving audit quality. Hence, it is assumed that they have a role in supporting the efficiency and independence of the auditor.

\section{Research outline}

In this section, the researchers will introduce the literature review, the hypotheses of the study, the conceptualization of joint audit and the auditor independence challenge. To prove the study hypotheses, the researcher can present the current methodology to achieve the conclusions of the study.

\section{Literature Review and Hypotheses Development}

In this section, the related literature is reviewed and the hypotheses are developed.

In (2012), Baldauf and steckel declared the effects of using joint audit on consensus and accuracy of the auditor report. This study provided evidence that auditors who apply joint audit 
approach achieved higher accuracy and consensus. In light of this study on enhancing the quality of audits by activating new regulations and programs, these findings are significant for both practicing of the audit and audit research. The research showed that joint opinions are more indicative and reasonable of higher quality and demonstrated the need for more investigation of the determinants of auditing process performance when using the approach of joint audit. It discovered that a joint audit has a positive impact on report accuracy. The auditors also used an expected opinion as a method for the measurement of the auditor report accuracy. On the other hand, the study provided the evidence that two joint auditors working one another produce more accurate opinion.

Zerni, et al. (2012) discussed the effect of voluntarily implementing of joint audits on the audit quality, using a group of companies in Sweden, which apply joint audit on optional basis. As a conclusion of the study: First, the implementation of the joint audit for both private and public firms can be associated with highly earnings conservatism. Second, joint liability is divided between both auditors to bear the risk of audit, which results from the probability that the other auditor may fail to perform his audit work share. Third, the study declared that applying joint audits can be associated with lower income, increasing abnormal accruals and this enhances audit quality. Forth, the implementation of joint audit can cause substantial increasing in the audit fees that were paid by the client, so this

required a higher quality level.

The study of Deng, et al. (2014) illustrated that joint audits by one big firm and one small firm may reduce audit quality; joint audits induce a free-riding problem between audit firms and reduce audit evidence precision. The study declared that though two heads may be better than one, free riding can reduce the information precision, and thus will reduce audit quality and 
information quality also under a joint audit by one big audit firm and one small audit firm in comparison with an audit by a single audit firm. Moreover, a single big audit firm dominates the market because the information quality under joint audits is not

higher than under a single big audit firm.

Because Egypt is considered one of the countries that the companies Laws No.159 of 1981 allows for the joint stock companies to contract with more than auditor at the same time to audit the same financial statements according to the study of ( $\mathrm{Al}$ Diasti, 2014). The researcher found the importance of examining the quality of joint audits in the Egyptian environment, in the light of the controversy in European countries. Joint audit quality has been tested as opposed to individual audit through the use of abnormal accruals to identify the extent restrict the practices of earnings management. The results didn't show a significant difference between joint and individual audit. Moreover, there weren't any differences in the audit quality between joint audit programs by one of the international audit firms and other programs without such these international audit firms.

Moreover, Ittonen and Tronnes (2015) discussed the impact of applying voluntary joint audits (in which two audit partners participate in the audit process) on the audit fees and audit quality. As a conclusion of the study, joint engagement partners could lead to higher audit quality than single audit by dominant auditor, in addition to less audit fees. The study also declared the difference between the single and joint audit regarding the effectiveness of the audit process, as cooperation between two audit partners in the same audit firm could raise the effectiveness of the audit process, while cooperation between auditors from different firms could enhance the efficiency in comparison with a single partner audit.

Youssef (2015) aimed to test the impact of joint audits on the audit quality through testing joint audit capability in enhancing 
the auditor's ability to detect fraud and report about it in the financial statements. In order to achieve this goal, an experimental case has been developed for financial statements which contain substantial distortions resulted from the fraud to determine the fraud risk and accuracy of the auditor's report who perform the audit process using joint audit programs compared to others using individual audit. As a conclusion of the study, the auditors using joint audits had higher assessment for fraud risks in the financial statements than other auditors using individual audits. The results also showed that the opinion of audit process was more correct in case of joint audits compared to individual audit; this could lead to the efficiency of the auditors who perform the joint audits in detecting fraud and reporting about it, in comparison with the other auditors who perform individual audits.

Moreover, Rusmanto (2016) studied the effect of audit firm size and its services to the clients on auditor independence using a group of auditors in Indonesia who worked for big, medium and small audit firms. It is supposed that audit firms have different size which contains different number of auditors, in addition to the services provided to their clients._As a result for growing some audit firms such as big-four, they are linked world-wide. Many previous studies concluded that there were a close positive relationship between the size of audit firm and independence of the auditor.

In the same context, another study by Albaqali and Kukreja (2017) handled the factors influencing the independence of auditors in Bahrain. They tried to assess many factors which help in enhancing objectivity and decrease threats of audit profession. The questionnaires were distributed to a number of auditors in Bahrain audit firms. The research encouraged the application of joint audits for the listed companies, in addition to determining 
the fairness as a main factor related to the independence of auditor.

One of the researches handled the pros and cons of joint audits in a clear way through using a Likert- type questionnaire which was directed to accountants, auditors and accounting academics in Nigeria. The questions were tested through simple percentages in addition to independent t-test statistics (Okaro, et al.2018).It aimed to help policy makers in understanding the advantages and disadvantages of joint audits in Nigeria, also assisting regulators making joint audit obligatory. They found that voluntary joint audit is desirable in Nigeria because its advantages increased over its costs. It had a beneficial effect on audit quality. According to accountants \& auditors point of view, joint audit shouldn't be made compulsory in the public companies, but accounting academics supported the idea

of making it mandatory.

Another study by Marnet and others (2019) discussed the contribution of joint audit in the audit process and what about its role in supporting audit quality through cognitive bias mitigation. The results explored that cognitive bias might affect the application and maintenance of the professional skepticism. The study suggested that joint audit arrangements might enhance the quality of audit through mitigating biases that affect auditor judgement. Finally, the researcher found a positive contribution of joint audit on the quality of the audit process.

Moreover, Abdelmoula (2020) handled a sample of two hundred and fifty companies in Tunisia and the study data was collected through a questionnaire. It discussed the determining factors of the quality of joint audit through three essential factors (Independence, competence and reputation). To prove the results of this study, the researcher determined a number of 120 banking institutions in addition to 130 insurance companies. The finding of the study indicated that the consequences of the study 
illustrated that the impact of independence on achieving acceptable joint audit quality is considered insignificant in case of the poor quality. After implementing the multinominal logistic regression, the study as a whole examined the effects of the previous factors in addition to their role in supporting the quality of joint audit. In deep, the joint audit mission quality contributed to the prediction process, as the three factors which named (reputation, competence \& independence) can significantly affect

\section{Previous studies declared that:}

$\checkmark$ Previous studies have declared that applying the joint audit approach may be an effective mechanism to improve the quality of audit; hence support auditors' independence, as assigning the audit process to more than one auditor in different audit and accounting firms can encourage competencies and maintains experienced people.

$\checkmark$ Moreover, the mechanism of activating joint audit programs can help in emergence of new audit firms other than the Big-4.

$\checkmark$ Few studies found that the joint audit may have a negative impact on the audit quality, in addition to threatening the independence of auditor compared to the individual audit.

$\checkmark$ Finally, the authors find that the programs of joint audit became controversial in recent times, in addition to the need to know its impact on the Egyptian environment. As the contribution of using joint audit programs should be beneficiary for Egyptian companies, banks, and audit firms.

Therefore the study hypotheses can be developed as follows: 
H1: "There are no significant differences among the sample members around the effect of joint audit on auditor independence".

$\mathrm{H} 2$ : "There is no significant impact of joint audit on increasing efficiency of the auditor".

H3: "There is no significant relationship between joint audit and auditor independence".

H4: "There is no significant impact of joint audit application on auditor independence".

\section{Joint Audit Conceptualization}

\subsection{Definition}

The global financial crisis is considered as one of the worst crises in economic history, which appeared many financial scandals in the world of business. All these events were a reason for reducing the credibility of published financial information (Yousef, 2015). In order to cope with this crisis, many new mechanisms were adopted for more control to solve the problem and regain confidence in the quality of published financial statements through improving the audit quality (Al Haridy, 2015). One of the first attempts which aimed to enhance audit quality and support the independence of auditors was SarbanesOxley Act (SOX) by U.S. Congress in 2002 to improve corporate governance, enhance the quality of audit and ensure auditor independence through providing a group of mechanisms such as (Auditor Rotation which means replacing the auditor with another after a certain period of time) according to Al Assy

The European commission suggested a group of actions to deal correctly with the audit market concentration and a lack of confidence in the independence of auditor; one of these actions was audit committee, auditor rotation and finally joint audit programs (Al Assy, 2015). A lot of researchers paid attention to 
the joint audit entrance and defended it at all levels, as they thought its role in supporting audit quality and independence of auditor. Generally, join audit may require only one audit report in which more than auditors discuss closely about the work of the same client, share the responsibility to issue fair and accurate financial statements free from material misstatements (Ratzinger et al., 2012). These programs have been implemented either voluntary or mandatory in many countries.

A lot of researchers defined the joint audit according their point of view.

Ibrahim (2018) defined the joint audit as a form of auditing in which more than one auditor cooperate to perform the audit function in all its steps starting from the audit plan to issuing the final report for auditing, but all auditors are responsible for the report and the work of each one in front of the client.

Ratzinger et al. (2012) conceptualized joint audit as a mechanism to deal with the perceived deficiencies in the function of audit which appeared following the financial crisis. It required two independent audit firms cooperate one another in order to encourage their auditor working hardly together, enhance auditor independence, unify cooperation in addition to professional harmony, and product just one report that handles the right position of the client.

The authors think that all the previous definitions are convergent and lead to the same meaning and purpose, so we can define the joint audit as a type of an external audit in which more than auditor from different firms collaborate with each other in order to observe the audit process, make an accurate final report about the work of the client, participate the responsibility and effort, result in higher level of audit quality.

4.2 Forms of joint audit

Generally we have to know that the market of audit can be segmented into two main parts: 
Large \& small auditors

$\square$ Big-4 \& Non big-4

Previous information will lead us to illustrate the following: The process of joint audit can be performed through two audit firms from (Big-4). The process of joint audit can be performed also through one audit firm from (Big-4) and another one of (Non big-4). It can be performed additionally through (Non big-4) audit firms (Ibrahim, 2018; Sakel et al., 2012 \& Al Hadi, 2017).

\subsection{Fundamental reasons to consider the programs of joint audit}

In case of more than one auditor, entities will benefit from the technical expertise and reduce the collusion between management and auditors (Marmousez, 2009). Reinforce independence of the auditor through decreasing • the risk of over-familiarity (Wahdan, 2019). Improve audit quality through encouraging continuity of • services and possessing more than one eye. Allocate the tasks of work between more than audit firm • will promote cooperation and coordination among auditors, which stimulates awareness and innovation (Okaro et al., 2018 \& Wahdan, 2019). Introduce just one joint report to express the auditor • opinion in the financial statements and achieve reasonable assurance about them (free from deviation and material misstatement).

\subsection{Advantages of joint audit programs}

* Joint auditors may always be rotated, so the programs of joint audit can help in alleviating the risk of overfamiliarity with any clients (Okaro et al., 2018; Hussein, 2018; Saleh, 2019). 
* They encourage reducing the dominance of audit market, this will lead to high competition among the audit firms and improve the quality of audit (Benali, 2013; Ibrahim, 2018).

* Encourage more discussion between the team of audit process and this will help in acquiring more experiences between big and small auditors (Metwaly, 2013; Wahdan, 2019).

- Increase the level of professional skepticism, so every auditor does his effort to perform the process of audit effectively (Marnet et al, 2019).

* Reduce the expectations gap through exchanging information and experience among auditors, affording common legal responsibility and distributing audit tasks between joint auditors (Mandour et al, 2018).

\subsection{Challenges of joint audits}

Beside the useful aspects of joint audits, many studies have found negative results of them. Among these negative impacts the following:

- Joint audit may have a problem of free-rider, which means neglecting the responsibility of one auditor relying on the other to perform all work (Francis et al, 2009; Okaro et al., 2018).

- Joint audit may be costly in comparison with individual one (Deng et al, 2014; Andre et al., 2016). It requires more time in consulting and coordination among auditors.

- There is difficulty in choosing the auditors, especially for the big companies because of audit firm's lack, in addition 


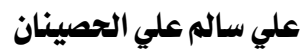

to the presence of communication and coordination problems between joint auditors (Ibrahim, 2018).

- The approach of joint audit may give an opportunity for the problem of opinion shopping because of competition among auditors which means the collusion with one audit firm in order to achieve the desirable report for special client (Deng et al, 2014).

\subsection{Joint audit determinants}

According to Al Assy. (2015), there are some factors affecting the company's decisions to implement joint audit programs as follows (see figure 1): -The big size companies may activate the joint audit programs because of having high levels of financial leverage in comparison with small size companies (Al Assy, 2015; Maggina, 2012). -Audit committee as one of corporate governance mechanisms can exert pressure on the company management to deal with the big-4 auditors in order to guarantee audit quality improvements (Marmousez, 2012; Al Assy, 2015). 


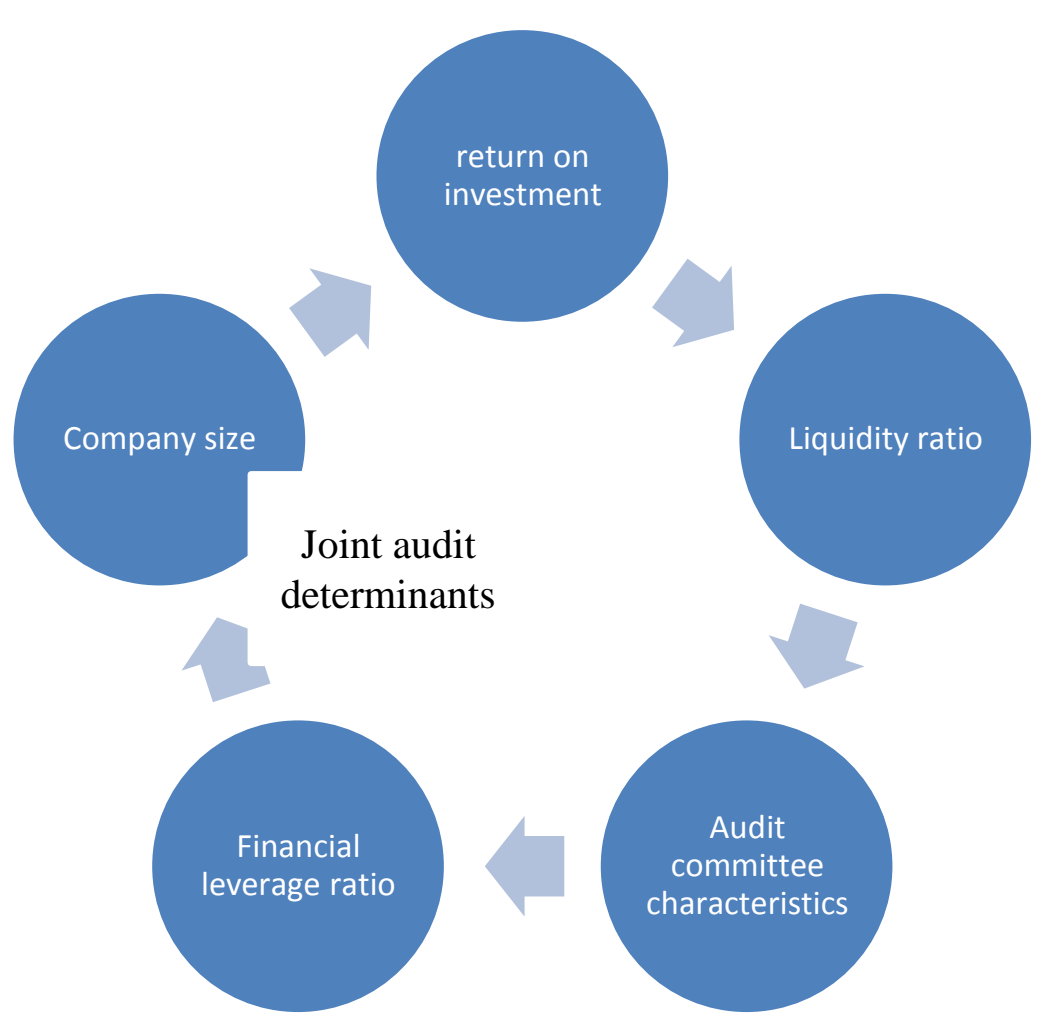

Figure (1): Determinants of joint audit

(Source: authors)

\section{Auditor Independence challenge}

\subsection{Definition of auditor independence}

Many researchers have introduced the definition of auditor independence. According to Baldauf and Steckel., 2012, the independence of auditor can be defined as the freedom from any pressure and restrictions which may cause the failure of auditing process, reduce the ability of auditor to illustrate the real image of the financial statements and formulate unbiased judgment of audit.

Other researcher defined auditor independence as the attitude which includes many values of honesty, objectivity and integrity to help him performing the audit process without 
any restrictions from the company management (Albaqali and Kukreja., 2017). The authors can summarize the mean of auditor independence as a challenge in which auditor should free from any restrictions that threaten the accuracy of the financial statements, and the auditor has to possess some values such as competence, objectivity and integrity helping him to express his fair opinion.

\subsection{Forms of auditor independence}

Independence can be classified in to two parts:

- Independence of mind (real independence).

- Independence in appearance (Perceived independence).

\section{Independence of mind}

It means the mind state which leads to satisfying conclusion regardless any external influences that compromise the professional judgment, hence allowing the auditor to act with objectivity, integrity and more professional skepticism (in which auditors may be influenced by a group of factors plus the independence such as: the education, knowledge training, culture of the audit firm, the relationship between management and the auditor. At all levels, independence can play a positive role in supporting the audit quality through professional skepticism.

(Mills et al., 2013).

\section{Independence in appearance}

It refers to the absence of circumstances and facts which would cause a reasonable and informed third party, having knowledge of the related information to conclude that the objectivity, integrity, or the professional skepticism has been compromised (Ottaway, 2012 \& Mills et al., 2012).

\subsection{The importance of auditor independence}


The auditor independence issue is considered as a critical element for the audit profession.

- Independence is the main important standard of auditing process because the auditor can add value to the financial statements, enhance its credibility, express it fairly, and ensure that they are free from material misstatement and fraud (Alaqali \& Kukreja, 2017).

- Many users of financial statements don't have sufficient knowledge about the existing information inside them, so they depend on the opinion of the independent auditor about the fairness of financial statements (Wahdan, 2006).

- Independence is the main cornerstone to improve the control structure in the joint stock companies.

- The lack of auditor independence will lead auditors to make wrong decisions, and then it will be the reason for bigger problems which may cause bankruptcy and business damages (Ghosh and moon 2004).

\subsection{Standards of the work of another auditor:}

ISA 600 illustrated some rules about using a work of another auditor intervened in the corporation financial statements as

follows:

- The auditor should determine the effects of other auditor

$$
\text { work on the audit process. }
$$

The auditor should have sufficient evidence that the other • auditor work for the same purpose and introduced fair opinion

about the financial statements.

- In the case of concluding unreliable findings, the principal auditor should declare his opinion depending on a qualified or disclaimer opinion and stop performing additional procedures 
regarding the process of audit (IFAC, 2004 ; Guy et al., 2003

\& Wahdan, 2006).

\subsection{Enhancing versus threatening factors of auditor independence}

We can illustrate the factors which affect the independence as

\section{Enhancing factors}

- Audit committee

- Professional commitment

- Auditor rotation

- Disclosure about financial relationships

- Auditor ethics

- Auditor reputation

- Perceived pressure

- Audit firm size

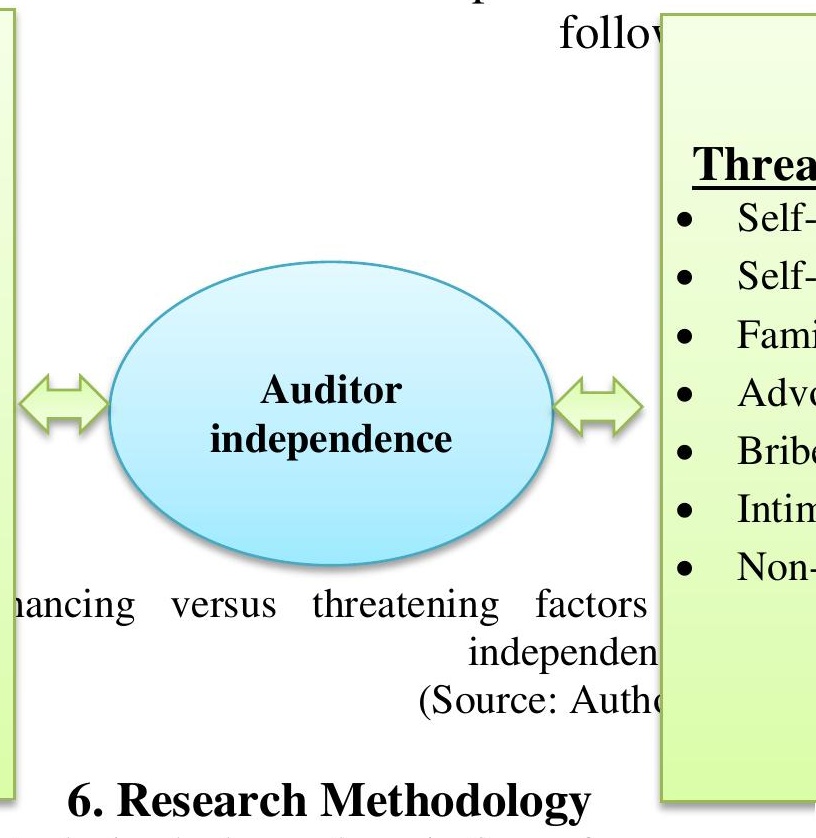

Methodology of the field study includes a description of the audit firms applied the joint audit programs in Egyptian environment, society, sample and methods of data

collection.

\section{Data Collection:}

The authors depended on the following resource to achieve the main study objective: -The questionnaire list is considered as a basic tool for collecting the needed data about the role of joint audit in supporting the auditor independence, and the researchers depended on some previous Arabic and foreign studies to help in preparing the desired questionnaire about the field study. 
-The researchers used the questionnaire list to collect the needed data and information through the chosen sample of auditors and academics introduced by the previous

population.

\section{Population and Sample:}

The authors distributed the questionnaire lists with in the selected audit firms, as these firms already applied joint audits related to the study. The study sample consisted of (51) auditor from the big audit firms, (79) auditor from the non-big audit firms and (50) of academics. The final number of questionnaire lists totaled (180). The lists were distributed to the study sample to answer in specific time, and then the data were collected and statistically analyzed after testing statistical viability for the normal distribution

of data.

Table (1): Distribution of the study sample according to the scientific qualification

\begin{tabular}{|r|r|r|}
\hline Qualification & Frequency & Percent \\
\hline BSc & 97 & 53.9 \\
\hline Diploma & 26 & 14.4 \\
\hline MSc & 38 & 21.1 \\
\hline PhD & 19 & 10.6 \\
\hline Total & 180 & 100.0 \\
\hline
\end{tabular}

(Source: authors' calculation)

The previous table (1) illustrates that a big number of the respondents have a high level of education (Diploma, MSc and $\mathrm{PhD})$, as they represent $(46.1 \%)$ about half of the respondents. Table (2): Distribution of the study sample according to experience in the auditing field

\begin{tabular}{|r|r|r|}
\hline $\begin{array}{r}\text { Experience in } \\
\text { academic and audit }\end{array}$ & Frequency & Percent \\
\hline
\end{tabular}




\section{علي سالم علي الحصينان}

تخليل أثر اقتصاد الععرفة على التنمية الستدامة في الكويتل

\begin{tabular}{|r|r|r|}
\hline Less than 5 years & 71 & 39.4 \\
\hline 5 years to less than 10 years & 64 & 35.6 \\
\hline 10 years to less than15 years & 27 & 15.0 \\
\hline 15 years and more & 18 & 10.0 \\
\hline Total & 180 & 100.0 \\
\hline
\end{tabular}

(Source: authors' calculation)

The table (2) declares the high level of academic and auditing experience, as (60.6) of the respondents have more than 5 years of experience and deal with their profession for a reasonable period.

Our study focused on two types of audit firms, in addition to the academics in most Egyptian universities to collect the required data as follows: (Big 4 audit firms, Non-big 4 audit firms, and academics).

\section{Study Variables:}

Independent variable $(\mathrm{X})$ is joint audit includes a number of variables totaled (37) factors \& Dependent variable (Y) is auditor independence which includes other number of variables totaled

(40) factors.

\section{Statistical techniques}

Many statistical techniques have been used in the study as follows: Descriptive Analysis, Cronbach's Alpha, One-Sample Kolmogorov Smirnov Test, Correlation, and Regression Analysis. 


\section{The Validity and reliability of the study variables}

To determine the efficiency of the questionnaire list, the authors can use the test of Cronbach's Alpha which measures the reliability and stability of the survey. According to statistical standards, we can accept the value in case of the desired limits (equal or greater than $60 \%$ ) in order to apply the results to the study population.

\section{The reliability of measurements in the study}

It means that the same results of measurements will be given in case of redistributing them any time and under the same conditions. To test the reliability and stability of the questionnaire, Cronbach's Alpha test is used.

\section{The validity of the items in the study}

The validity of any measurements was confirmed through the reliability coefficient, as it was one of the main statistical methods.

Table (3): The reliability $\&$ validity of the basic variables in the survey

\begin{tabular}{|lrrrrr|}
\hline $\begin{array}{r}\text { The basic axes of } \\
\text { the } \\
\text { questionnaire }\end{array}$ & Coding & $\begin{array}{r}\text { Number of } \\
\text { statements }\end{array}$ & $\begin{array}{r}\text { Reliability } \\
\text { coefficient }\end{array}$ & $\begin{array}{r}\text { Validity } \\
\text { coefficient }\end{array}$ \\
\hline $\begin{array}{r}\text { Motivation to } \\
\text { apply joint audit }\end{array}$ & $\mathrm{X} 1$ & 7 & 0.731 & 0.775 \\
\hline $\begin{array}{l}\text { Mechanisms for } \\
\text { applying joint }\end{array}$ & $\mathrm{X} 2$ & 7 & 0.647 & 0.738 \\
\hline Yq & & & & \\
\hline
\end{tabular}




\begin{tabular}{|c|c|c|c|c|}
\hline $\begin{array}{r}\text { The basic axes of } \\
\text { the } \\
\text { questionnaire }\end{array}$ & Coding & $\begin{array}{r}\text { Number of } \\
\text { statements }\end{array}$ & $\begin{array}{l}\text { Reliability } \\
\text { coefficient }\end{array}$ & $\begin{array}{r}\text { Validity } \\
\text { coefficient }\end{array}$ \\
\hline audit & & & & \\
\hline $\begin{array}{lr}\text { Advantages } & \begin{array}{r}\text { of } \\
\text { applying }\end{array} \\
& \text { joint } \\
\text { audit }\end{array}$ & $\mathrm{X} 3$ & 16 & 0.896 & 0.909 \\
\hline $\begin{array}{c}\text { Challenges to } \\
\text { apply joint audit }\end{array}$ & $\mathrm{X} 4$ & 7 & 0.819 & 0.618 \\
\hline Total $(\mathbf{X})$ & & 37 & 0.912 & 0.987 \\
\hline $\begin{array}{c}\text { Independent } \\
\text { auditor role }\end{array}$ & Y1 & 5 & 0.681 & 0.572 \\
\hline $\begin{array}{l}\text { Requirements for } \\
\text { supporting the } \\
\text { auditor efficiency }\end{array}$ & Y2 & 7 & 0.852 & 0.766 \\
\hline $\begin{array}{r}\text { Auditor } \\
\text { independence } \\
\text { importance }\end{array}$ & Y3 & 5 & 0.753 & 0.694 \\
\hline $\begin{array}{rr}\begin{array}{r}\text { Positive } \\
\text { affecting }\end{array} & \begin{array}{r}\text { factors } \\
\text { the } \\
\text { auditor }\end{array} \\
\text { independence }\end{array}$ & Y4 & 12 & 0.824 & 0.873 \\
\hline $\begin{array}{r}\text { Risks which could } \\
\text { threaten the } \\
\text { auditor } \\
\text { independence }\end{array}$ & Y5 & 11 & 0.906 & 0.833 \\
\hline Total $(\mathbf{Y})$ & & 40 & 0.931 & 0.985 \\
\hline Total (X \&Y) & & 77 & 0.950 & 0.898 \\
\hline
\end{tabular}

(Source: authors' calculation)

The previous table (3) refers to the following information:

The value of the reliability coefficient generally for all axes (X $\& Y)$ is equal (0.950) which is greater than $(60 \%)$, so this is statistically acceptable value. 
The reliability coefficient values related to the questions and statements of independent variable (X) in the questionnaire are (0.731, 0.647, $0.896 \& 0.819)$, all these values are more than $60 \%$ so they are statistically good. Total $(\mathrm{X})$ is equal 0.912 , which also is considered as acceptable value.

* The reliability coefficient values of all questions related to the dependent variable $(\mathrm{Y})$ in the survey are $(0.681,0.852,0.753$, $0.824 \& 0.906)$, and the total value of $(\mathrm{Y})$ is $(0.931)$. All the previous values are statistically good, as they are greater than $60 \%$.

* Moreover, the validity coefficient value in general is (0.898), which is statistically acceptable. The values of the validity coefficient for all $(\mathrm{X} \& \mathrm{Y})$ axes of the questionnaire list are $(0.775,0.738,0.909,0.618,0.572,0.766,0.694,0.873$ and 0.833 ), so all the previous values are statistically good, as the validity coefficient equal $60 \%$.

* Finally, it is noted that all the statements and questions of the survey have a high degree of the internal consistency and reliability, so the researchers can depend on them to achieve the study objectives and get more reliable results that are beneficial to the population of the study.

Hypotheses testing 


\section{The first hypothesis of the study}

"There are no significant differences among the sample members around the effect of joint audit on auditor independence". To test this hypothesis, the researchers can use (Kruskal-Wallis Test) which aims to test the significance of differences in the mean among the samples of study (auditors in big audit firms, auditors in non-big audit firms \& academics in Egyptian universities) about the role of joint audit in supporting the auditor independence. This test declares whether there are differences among the opinions of the samples on joint audit (X) and auditor independence (Y). Table (4) can explain the results of Kruskal-

Wallis Test as follow:

Table (4): Kruskal-Wallis test results related to the effect of joint audit on auditor independence

\begin{tabular}{|c|c|c|c|c|c|}
\hline & & & Mean Rank & $\begin{array}{r}\mathbf{K r} \\
\text { Wallis }\end{array}$ & \\
\hline Axes & $\begin{array}{l}\text { Auditors } \\
\text { in big } \\
\text { audit firms }\end{array}$ & $\begin{array}{r}\text { Auditors } \\
\text { in non-big } \\
\text { audit } \\
\text { firms }\end{array}$ & $\begin{array}{r}\text { Academics } \\
\text { in } \\
\text { Egyptian } \\
\text { universities }\end{array}$ & $\begin{array}{r}\text { Chi- } \\
\text { Square }\end{array}$ & va \\
\hline $\begin{array}{r}\text { Motivation to apply joint } \\
\text { audit. }\end{array}$ & 75.47 & 96.67 & 96.08 & 5.981 & \\
\hline $\begin{array}{cc}\text { Mechanisms for } & \text { for } \\
\text { applying joint audit. }\end{array}$ & 83.42 & 92.29 & 94.89 & 1.408 & \\
\hline $\begin{array}{r}\text { Advantages of applying } \\
\text { joint audit. }\end{array}$ & 77.41 & 92.63 & 100.49 & 5.207 & \\
\hline $\begin{array}{r}\text { Challenges to apply joint } \\
\text { audit. }\end{array}$ & 85.71 & 81.89 & 108.99 & 8.937 & \\
\hline
\end{tabular}




\begin{tabular}{|c|c|c|c|c|c|}
\hline & & \multicolumn{2}{|c|}{ Mean Rank } & \multicolumn{2}{|c|}{\begin{tabular}{l}
\multicolumn{2}{r}{ Krusk } \\
Wallis T
\end{tabular}} \\
\hline $\begin{array}{cc}\text { Independent } & \begin{array}{c}\text { auditor } \\
\text { role. }\end{array}\end{array}$ & 88.67 & 94.75 & 85.66 & 1.037 & 0 . \\
\hline $\begin{array}{r}\text { Requirements for } \\
\text { supporting the auditor } \\
\text { efficiency. }\end{array}$ & 79.79 & 97.24 & 90.77 & 3.550 & 0 . \\
\hline $\begin{array}{cc}\text { Auditor } & \begin{array}{c}\text { independence } \\
\text { importance. }\end{array}\end{array}$ & 79.41 & 97.16 & 91.28 & 3.737 & 0. \\
\hline $\begin{array}{l}\text { Positive factors affecting } \\
\text { the auditor } \\
\text { independence }\end{array}$ & 90.15 & 91.87 & 88.70 & 0.117 & 0 . \\
\hline $\begin{array}{lcr}\text { Risks } & \text { which } & \text { could } \\
\text { threaten } & \text { the auditor } \\
& \text { independence }\end{array}$ & 89.39 & 83.84 & 102.15 & 3.841 & 0 \\
\hline
\end{tabular}

(Source: authors' calculation)

The results of Kruskal-Wallis test according to table (4) show that there are no differences among the sample members around (mechanisms for applying joint audit, advantages of applying requirements for supporting joint audit, independent auditor role the auditor efficiency, auditor independence importance, positive factors affecting the auditor independence, risks which could threaten the auditor independence) because the significance level is more than $5 \%$.

The results also declared that there are differences among the study sample regarding the motivation to apply joint audit (as the significance level 5\%), also the challenges to apply joint audit is less than $5 \%$. 


\section{علي سالم علي الحصينان}

تحليل أثر اقتصاد المعرفة على التنمية الستدامة في الكويتل

Table (5): Kruskal-Wallis test results according to the scientific qualification

\begin{tabular}{|c|c|c|c|c|c|c|}
\hline \multirow{2}{*}{ Axes } & \multicolumn{4}{|c|}{ Mean Rank } & \multicolumn{2}{|c|}{ Kruskal-V } \\
\hline & BSc & Diploma & MSc & PhD & $\begin{array}{r}\text { Chi- } \\
\text { Square }\end{array}$ & P- \\
\hline $\begin{array}{r}\text { Motivation to apply joint } \\
\text { audit }\end{array}$ & 82.46 & 101.90 & 96.04 & 104.84 & 5.473 & \\
\hline $\begin{array}{r}\text { Mechanisms for applying } \\
\text { joint audit }\end{array}$ & 82.46 & 90.54 & $\begin{array}{r}109.1 \\
1\end{array}$ & 94.26 & 7.347 & \\
\hline $\begin{array}{l}\text { Advantages of applying } \\
\text { joint audit }\end{array}$ & 83.55 & 93.19 & 99.41 & 104.47 & 4.288 & \\
\hline $\begin{array}{r}\text { hallenges to apply joint } \\
\text { audit }\end{array}$ & 79.65 & 81.29 & $\begin{array}{r}110.1 \\
3\end{array}$ & 119.21 & 16.275 & \\
\hline Independent auditor role & 87.77 & 91.87 & 96.13 & 91.32 & 0.746 & \\
\hline $\begin{array}{l}\text { Requirements } \\
\text { upporting the } \\
\text { efficiency }\end{array}$ & 89.31 & 95.58 & 88.51 & 93.61 & 0.429 & \\
\hline $\begin{array}{c}\text { independence } \\
\text { importance }\end{array}$ & 84.74 & 103.85 & 86.04 & 110.55 & 6.187 & \\
\hline $\begin{array}{l}\text { ositive factors affecting } \\
\text { the auditor independence }\end{array}$ & 85.22 & 95.50 & 94.29 & 103.03 & 2.549 & \\
\hline $\begin{array}{lcr}\text { Risks } & \text { which could } \\
\text { hreaten } & \begin{array}{c}\text { the auditor } \\
\text { independence }\end{array}\end{array}$ & 85.02 & 83.46 & $\begin{array}{r}100.0 \\
9\end{array}$ & 108.92 & 5.249 & \\
\hline
\end{tabular}

(Source: authors' calculation)

The table (5) proves that there are no differences between the sample opinions according to the scientific qualification around all variables (X1, X2, X3, Y1, Y2, Y3, Y4, Y5), because all of them are more than $5 \%$ except the forth independent variable (challenges to apply joint audit) which decreases to 0.01 . 
Table (6): Kruskal-Wallis test results according to years of experience in the auditing field

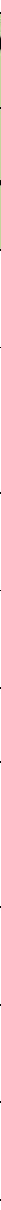

(Source: authors' calculation)

The results of table (6) show that there are no differences between the study samples according to the years of experience regarding all the variables:

Motivation to apply joint audit.

Mechanisms for applying joint audit. 


\section{علي سالم علي الحصينان}

Advantages of applying joint audit.

Challenges to apply joint audit.

Independent auditor role.

Requirements for supporting the auditor efficiency.

Auditor independence importance.

Positive factors affecting the auditor independence.

Risks which could threaten the auditor independence.

As all the previous variables are more than 5\% (significance level).

Finally, the researchers can accept the study hypothesis: "There are no significant differences among the sample members around the effect of joint audit on auditor independence".

\section{Testing the second hypothesis:}

$\mathrm{H} 2$ : "There is no significant impact of joint audit on increasing efficiency of the auditor".

We can consider the following table (7), which explains the results of regression analysis as follows:

Table (7): The results of regression test related to the most important variables affecting Y2: Requirements for supporting the auditor efficiency.

\begin{tabular}{|c|c|c|c|c|c|c|}
\hline \multirow{2}{*}{ Variables } & \multicolumn{2}{|c|}{$\begin{array}{r}\text { Unstandardized } \\
\text { Coefficients }\end{array}$} & \multirow{2}{*}{$\begin{array}{r}\text { Standardize } \\
\text { d } \\
\text { Coefficients }\end{array}$} & \multirow{2}{*}{$\mathbf{T}$} & \multirow{2}{*}{$\begin{array}{r}\text { P- } \\
\text { value }\end{array}$} & \multirow{2}{*}{ VIF } \\
\hline & B & Std.Error & & & & \\
\hline $\begin{array}{l}\text { Motivation to } \\
\text { apply joint }\end{array}$ & 0.040 & 0.074 & 0.044 & 0.537 & 0.592 & 1.892 \\
\hline
\end{tabular}




\begin{tabular}{|r|r|r|r|r|r|l|}
\hline 2 & & & & & \\
\hline $\begin{array}{r}\text { Mechanisms } \\
\text { for } \begin{array}{r}\text { applying } \\
\text { joint audit }\end{array}\end{array}$ & 0.177 & 0.073 & 0.185 & 2.413 & 0.017 & 1.655 \\
\hline $\begin{array}{r}\text { Advantages of } \\
\text { applying joint } \\
\text { audit }\end{array}$ & 0.380 & 0.084 & 0.409 & 4.526 & 0.000 & 2.301 \\
\hline $\begin{array}{l}\text { Challenges to } \\
\text { apply joint } \\
\text { audit }\end{array}$ & 0.064 & 0.042 & 0.098 & 1.528 & 0.128 & 1.149 \\
\hline
\end{tabular}

\section{Correlation coefficient ( $\mathbf{R}$ )}

Determination Coefficient $\left(\mathbf{R}^{2}\right.$ )

\section{ted determination coefficient $\left(\mathrm{Adj} . \mathrm{R}^{2}\right)$}

\section{F-test}

\section{P-value}

(Source: authors' calculation).

Table (7) explains the following:

1) The regression analysis determines the most important predictive variables which affect the dependent variable (Y2: requirements for supporting the auditor efficiency) as follows:

Motivation to apply joint audit.

Mechanisms for applying joint audit.

Advantages of applying joint audit.

Challenges to apply joint audit. 
2) (P-value) in the step regression analysis can illustrate that the result has a statistical significance as the significance level is 0.000 (less than 5\%), which helps us in making the decision.

3) The significance of the whole model of regression can be tested through using (F-test) which is (26.640).

4) Through the values of $B$, we can arrange the independent variables according to the relative importance in supporting the auditor efficiency as follows:

冈 Advantages of applying joint audit $=0.380$.

冈 Mechanisms for applying joint audit $=0.177$.

$\bigotimes$ Challenges to apply joint audit $=0.064$.

冈 Motivation to apply joint audit $=0.040$.

5) The Variance Inflation Factor (VIF) for each variable $(1.892,1.655,2.301 \& 1.149)$, all of them are less than (10).

6) The Tolerance (TOL) is greater than (0.1) for all independent variables such as $(0.528,0.604,0.435 \&$ 0.871), which mean that there is no multilinearity between the explanatory variables, so we can depend on the results of this model. 
We can express the impact of $(\mathrm{X})$ on $(\mathrm{Y})$ through the next equation:

$$
\text { Y2 }=1.800+0.040 \times 1+0.177 \times 22+0.380 \times 33+0.064 \times 44 \text {. }
$$

Previously, we can refuse the second hypothesis which states the following:

$\mathrm{H} 2$ : "There is no significant impact of joint audit on increasing efficiency of the auditor", as There is significant impact of joint audit on increasing efficiency of the auditor.

\section{Testing the third hypothesis of the study}

"There is no significant relationship between joint audit and auditor independence". To test this previous hypothesis, the spearman coefficient will be used for correlation analysis and table (8) can illustrate the results of this test as follows:

Table (8): Matrix correlation coefficients between the basic

Variables (X \& Y)

\begin{tabular}{|r|r|r|r|}
\hline & Statistics & Joint Audit & $\begin{array}{r}\text { Auditor } \\
\text { Independence (Y) }\end{array}$ \\
\hline \multirow{2}{*}{ Joint Audit (X) } & $\begin{array}{r}\text { Correlation } \\
\text { coefficient } \\
\text { (Spearman) }\end{array}$ & 1 & $0.639^{* *}$ \\
\cline { 2 - 4 } & $\begin{array}{r}\text { Significance } \\
\text { level }\end{array}$ & & 0.000 \\
\hline $\begin{array}{r}\text { Auditor } \\
\text { Independence } \\
(\mathrm{Y})\end{array}$ & $\begin{array}{r}\text { Correlation } \\
\text { coefficient } \\
\text { (Spearman) }\end{array}$ & $0.639^{* *}$ & \\
\cline { 2 - 4 } & $\begin{array}{r}\text { Significance } \\
\text { level }\end{array}$ & 0.000 & \\
\hline
\end{tabular}




\section{علي سالم علي الحصينان}

تحليل أثر اقتصاد العرفة على التنمية الستدامة في الكويتل

Significance Level (0.01)

(Source: authors' calculation)

The last table (8) can explain the strong positive correlation between the basic variables (X, Y) (Joint audit \& Auditor independence), as the correlation coefficient is $(0.639 * *)$ according to the correlation of Spearman, and at a significance level of (1\%). It is also noted that there is an emphasis related to the statements validity which can be used to measure the variables of study, so the basic variables (X, Y) are truly linked, as result of the previous explanation, we can refuse the third hypothesis: "There is no significant relationship between joint audit and auditor independence", and accept the alternative hypothesis that there is a significant relationship between joint audit and auditor independence.

\section{Testing the forth hypothesis:}

H4: "There is no significant impact of joint audit application on the auditor independence".

We can consider the table (9) to illustrate the results of the backward regression analysis as follows:

Table (9): The results of regression test related to the most important variables affecting Y1: Independent auditor role

Variables

Unstandardized

coefficients
$\mathbf{T}$
P-value

VIF 


\begin{tabular}{|c|c|c|c|c|c|c|}
\hline & B & Std.Error & coefficients & & & \\
\hline $\begin{array}{l}\text { Motivation to } \\
\text { apply joint audit }\end{array}$ & 0.164 & 0.095 & 0.152 & $\begin{array}{r}1.72 \\
7\end{array}$ & 0.086 & 1.892 \\
\hline $\begin{array}{l}\text { Mechanisms for } \\
\text { applying joint } \\
\\
\\
\text { audit }\end{array}$ & 0.137 & 0.094 & 0.120 & $\begin{array}{r}1.46 \\
0\end{array}$ & 0.146 & 1.655 \\
\hline $\begin{array}{lr}\text { Advantages } & \text { of } \\
\text { applying } & \text { joint } \\
& \text { audit }\end{array}$ & 0.294 & 0.108 & 0.264 & $\begin{array}{r}2.72 \\
1\end{array}$ & 0.007 & 2.301 \\
\hline $\begin{array}{l}\text { Challenges to } \\
\text { apply joint audit }\end{array}$ & 0.108 & 0.054 & 0.137 & $\begin{array}{r}1.99 \\
7\end{array}$ & 0.047 & 1.149 \\
\hline
\end{tabular}

Correlation coefficient ( $\mathbf{R}$ )

Determination Coefficient $\left(\mathbf{R}^{2}\right.$ )

isted determination coefficient (Adj. $\mathbf{R}^{2}$ )

\section{F-test \\ P-value}

(Source: authors' calculation)

Table (9) declares the following information:

The regression analysis determines the most important predictive variables which affect the dependent variable (Y1: independent auditor role) as follows (X1: motivation to apply joint audit, X2: mechanisms for applying joint audit, X3: advantages of applying joint audit \& X4: challenges to apply joint audit). 
We can evaluate the accuracy of step regression analysis through the correlation coefficient $(\mathrm{R})$, which is $(0.532)$ that means a high correlation between the independent variables in the previous table and dependent variable (Y1: independent auditor role), then the determination coefficient (R2) reveals that the previous variables are contributing to illustrate $28 \%$ of the variation in (Y1) dependent variable.

(P-value) in the step regression analysis can illustrate that the result has a statistical significance as the significance level is 0.000 (less than 5\%), which helps us in making the decision.

* The significance of the whole model of regression can be tested through using (F-test) which is (17.307).

* Through the values of $\mathrm{B}$, we can arrange the independent variables according to the relative importance in the independent auditor role as follows:

○ X3: Advantages of applying joint audit $=0.294$.

○ X1: Motivation to apply joint audit $=0.164$.

○ X2: Mechanisms for applying joint audit $=0.137$.

○ X4: Challenges to apply joint audit $=0.108$.

* The Variance Inflation Factor (VIF) for each variable will be as follows $((1.892,1.655,2.301 \& 1.149)$, all of them are less than (10). 
* The Tolerance (TOL) is greater than (0.1) for all independent variables such as $(0.528,0.604,0.435 \& 0.871)$, which mean that there is no multilinearity between the explanatory variables, so we can depend on the results of this model.

We can use the next equation to declare the main result obviously:

$$
\text { Y1 } 1=1.283+0.164 X 1+0.137 X 2+0.294 X 33+0.108 \underline{X} 4 \text {. }
$$

So we can refuse the forth hypothesis (H4: "There is no significant impact of joint audit application on the auditor independence"), and accept the alternative hypothesis that there is a significant impact of joint audit application on the auditor independence.

\section{Conclusions, recommendations and future studies}

\subsection{Conclusions}

The most important advantage of applying joint audit is getting a reasonable assurance that the financial statements are free from material misstatements according to the opinions of the sample, but the least important one is reducing unemployment rate because of enhancing competition between audit firms. Moreover, the study illustrated that increasing the fees of auditing process is considered the most important challenge to 
apply joint audits according to the study sample opinions, as using more than audit firm requires more money to pay for them; so the big companies and banks can depend on the joint audit to revise the financial statements. On the other hand, (competition between audit firms may facilitate the collusion between client and one of the firms to get the desirable report) can be considered the least important challenge to apply the joint audit according to the sample opinions.

Moreover, the study showed that helping in the optimal distribution of client resources is considered the least important role of the independent auditor according to the sample opinions. The most study results illustrated that the fees play an important role in supporting the independence and choosing the programs of joint audits. Also, the findings of the study indicated that: (1) there are no significant differences among the sample members around the effect of joint audit on auditor independence according to (experience \& scientific qualification), (2) there is a significant impact of joint audit application on the auditor independence, (3) there is a significant impact of joint audit on increasing efficiency of the auditor, (4) there is a significant relationship between joint audit and auditor independence. 


\subsection{Limitations and future studies}

There is a limitation to generalize the study results, as the authors could depend on the different audit firms applied joint audits in Egypt. The authors determined a number of future studies related to the study such as: First, testing the impact of audit firm size on the joint audit programs in the Egyptian environment. Second, studying the impact of client company size on choosing the joint auditors in the Egyptian environment. Third, analyzing the relationship joint audit and increasing the auditors' efficiency.

\section{References}

Abdelmoula, L. (2020), "Impact of Auditor's Competence, Independence and Reputation on the Joint-Audit Quality: The Tunisian Context", Academy of Accounting and Financial Studies Journal, 24(3), PP 1:11. Al assy, M. G. (2015), "The Effect of Joint Audit on Audit Quality: Empirical Evidence from Companies Listed on the Egyptian Stock Exchange". International Journal of Accounting and Financial Reporting, 5(2), PP 195-207. Al Assy, M., (2015). "Studying and Testing the Effect of Adopting the Approach of External Joint Audit on the Audit Quality and Financial Reports for the Companies Listed on 
the Egyptian Stock Exchange", Master Thesis, Faculty of

Commerce, Alexandria University (In Arabic).

Al Diasti, M., (2014). "Joint Audit versus Individual Audit: An Empirical Study on the Extent to which Egyptian Audit Firms Restrict the Practices of Managing Earnings in JointStock Companies", Egyptian Journal of Trade Studies, Mansoura University, 38(1), PP. 19-39 (In Arabic). Al Khoury, F.A., Ali, A.,\& Al Sharif, M.,\& Hanania, J.,\& Malki, I.,\& Jallad, M., (2015), "Auditor Independence and Mandatory Auditor Rotation in Jordan", International Business Research, Vol.8, No.4, pp.73-82.

Albaqali, Q., Kukreja, G., (2017). "The Factors Influencing Auditor Independence: The Perceptions of Auditors in Bahrain". Corporate Ownership \& Control, 14(2), PP 369-

382.

Al-Hadi, A., Habib, A., Al-Yahyaee, K. and Eulaiwi, B., (2017), "Joint Audit, Political Connections and Cost of Debt Capital" . International Journal of Auditing , 21(3), pp. 249-270. Al Haridy, A., (2015). "The Impact of Joint Audits on the Quality of Financial Reports: An Empirical Study on Banks Listed in the Stock Exchange", Faculty of Commerce 
Journal for Scientific Research, Alexandria University, the first Issue, PP.111-154 (In Arabic).

Andre, P.,\& Broye, G.,\& Pong, C.,\& Schatt, A., (2016), "Are Joint Audits Associated With Higher Audit Fees?",

Forthcoming European Accounting Review, pp. 1-50. Baldauf, J., \& Steckel, R., (2012), "Joint Audit and Accuracy of the Auditor's Report: An Empirical Study", International Journal of Economic Sciences and Applied Research, 5(2),

$$
\text { pp. 7-42. }
$$

Benali, A. (2013), "The Shareholders Confidence and Effectiveness

the Joint Auditors: Empirical Validation in the French

Context".

International Journal of Business and Management, 8(11), pp. 21-42.

Davies, M., Mills, P., O’Nei, T., Brown, D., (2013). " Enhancing Audit Quality: Canadian Perspectives-Conclusions and Recommendations".

Deng, M.,\& Lu, T.,\& Simunic, D.A.,\& Ye.M., (2014), "Do Joint Audits Improve or Impair Audit Quality?", Rotman School of Management Working Paper No. 2111710; CAAA Annual Conference 2013 pp. 1-47. 
Francis, J. R., Richard, C., Vanstraelen, A., (2009), "Assessing France's Joint Audit Requirement: Are Two Heads Better than One?", A Journal of Practice \& Theory, 28 (2), pp. 35-

Ghosh, A., Moon, D. (2004). "Auditor Tenure and Perceptions of Audit Quality". Working paper, The Securities and Exchange Commission, Washington, DC. Guy, D.M., Carmichael, D.R., and Lach, L.A. (2003). "Practitioner's Guide to GAAS". John Wiley and Sons, Inc.,

Canada.

Hussein, A., (2018). "Joint Audit in the Egyptian Professional Environment: Comparative Study with a Proposed Framework", Scientific Journal, Faculty of Commerce, Asyut University, 64(3), PP.101-126 (In Arabic). Ibrahim, N., (2018). "The Impact of Appling Joint Audit on Earnings Quality and Firm's Value: An Empirical Study", Master thesis, Faculty of Commerce, Cairo University (In Arabic). IFAC (2004). "Handbook of International Auditing, Assurance and Ethics Pronouncements, International Federation of Accountants". Available at http:/www.ifac.org. 
Ittonen, K., Tronnes, P.C., (2015), "Benefits and Costs of Appointing Joint Audit Engagement Partners", Journal of Practice \& Theory, Vol.34, No. 3, pp. 23-46.

Maggina, A., (2012). "Joint Audit in Greece: Evidence from Greek Listed Companies", Working Paper. Available at: www.aahq.com.

Mandour, M., Elharidy, A., Mokhtar, E. (2018), "Examining The Effect of Joint and Dual Audits on Earnings Management Practices". International Journal of Accounting and Financial Reporting, Vol 8, No1, PP 84-114. Marmousez, S., (2009), "The choice of joint-auditors and earnings quality: Evidence from French listed companies".

Working Paper, Available at: www.ssrn.com. Marmouzes, S. (2012), "Examining a French Exception: The Determinants of the Choice of Joint Auditors", Managerial

Auditing Journal, 18(1), pp 121-152.

Marnet, O., Barone, E., Gwilliam, D. (2019), "Joint audit-a means to reduce bias and enhancescepticism in financial statement audits?"

Working Paper, availableat:https://ssrn.com/abstract=3300117, PP. 1-44. 


\section{علي سالم علي الحصينان}

Metwaly, A., (2013). "Measuring the Impact of Implementing

Joint Audit Programs on Stock Prices: Evidence from the Egyptian Stock Exchange", Scientific Journal of Trade and Finance, Faculty of Commerce, Tanta University, 4(2), PP. 401-459 (In Arabic).

Okaro, S., Okafor, G., Ofoegbu, G., (2018), "Mandating Joint Audits in Nigeria: Perspectives and Issues". International Journal of Academic Research, Vol. 8, No. 3 , March pp.316-338.

Ottaway, J., (2012). "Improving Auditor Independence in Australia: Is Mandatory Audit Firm Rotation the best Option?" Ratzinger, N., Audousset, S., Kettunen, J.,\& Lesage, C., (2012), "What Do We Know About Joint Audit?", The Institute of Chartered Accountants of Scotland, pp. 1-49. Ratzinger-Sakel, N., Audoussel-Coulier, S., Katunen, J., and Lesage, C., (2013), "Joint Audit Issues and Challenges for Researchers and Policy Makers". Accounting in Europe, 10(2), pp. 175-199. 
Rusmanto, T., (2016). "Do Audit Firm Size and Their Services Matter on Auditor Independence: A Case of Indonesia". Journal of Business Studies, 7(3), PP 1-16.

Saleh, S., (2019). "The Role of Electronic Brainstorming Programs of Audit Team Structure for Improving the Quality of Joint Audits", PhD Thesis, Faculty of Commerce, Suez Canal University (In Arabic).

Wahdan, M. A. (2006). "Automatic Formulation of the Auditor's Opinion". $\mathrm{PhD}$ Thesis, Maastricht, the Netherlands:

.Maastricht University.

Wahdan, M., (2019). "Evaluating the Impact of Joint Audit on Accounting Conservatism in the Light of the Auditor Industry Specialization: An Applied Study", Scientific Journal of Trade searches, Menofia University, 34(3), PP.996 (In Arabic).

Yousef, H., (2015). "The Effect of Activating the Joint Audit Approach on the Efficiency of the Auditor in Detecting and Reporting Fraud in the Financial Statements", Journal of Accounting Thought, Faculty of Commerce, Ain shams University, 2(1), PP.439-503 (In Arabic).

Zerni, M.,\& Haapamaki, E.,\& Jarvinen, T.,\& Niemi, L., (2012), "Do Joint Audits Improve Audit Quality? Evidence from 
Voluntary Joint Audits", European Accounting Review, 21(4), pp. 731-765. 